\title{
Study Creative Industry Sector Design, Fashion, Publishing and Printing in Jakarta and Bandung
}

\author{
Purnomo Ananto* \\ Publishing Department \\ State Polytechnic of Creative Media \\ Jakarta, Indonesia \\ *purnomo.ananto@polimedia.ac.id
}

\begin{abstract}
The creative industry is an industry that grows at the micro, small and medium scale stage with its distinctiveness emphasizing creativity in creating a product or service. The limitations of the creative industry in general are the problems of capital, marketing and supporting infrastructure. Given the many industry sectors that are relevant, in this study, researchers will limit the sectors of Design, Fashion, Publishing and Printing. The purpose of this research is to: (1) map the creative industries in the fields of Design, Fashion, cracking and publishing; and (2) To get an overview of students' understanding of the creative industry. This study uses quantitative methods supported by qualitative methods, but researchers also refer to the testing of paradigmatic logical inference (Quantitative Logic Inference). While the data is analyzed by regression techniques. The subjects of this study were students from 7 public and private high schools, as well as students from three state and private universities in Bandung and Jakarta. While from the business world as many as 15 research subjects engaged in Graphic Design and Printing, Fashion / fashion, convection and trade services, as well as secondary data obtained from local governments in Jakarta and Bandung. The results of this study are: (1) The description of the development of creative industries in Jakarta and Bandung is relatively the same, there are only a few sub-sectors of the creative industry that are special characteristics of each city, as in Bandung it is more prominent in fashion and textiles while in Jakarta it is more prominent in the field of software development and animation, as well as fashion; (2) The fashion creative industry subsector is still the most sought after business by creative industry players. This data is also supported by the fact that the number of fashion-related subsectors is far more than the other creative industry sub-sectors; and (3) The understanding of students in the field of creative industries still shows unsatisfactory results, because only $42 \%$ really understand what the creative industry is. The government, especially in Bandung and Jakarta, has to improve the infrastructure that can support the development of the creative industry, while also facilitating the credit process for business capital for actors and potential creative industry players. Furthermore, to get a more comprehensive picture of the results of this study, further research needs to be done with broader variables and research objectives.
\end{abstract}

Keywords-quantitative logic inference; creative industry players

\section{INTRODUCTION}

Indonesia's economic growth in 2016 reached 5.02 percent. This figure is higher than 2015 which was corrected by 4.88 percent. Similarly, the realization of this growth was also higher than in 2014 which amounted to 5.01 percent, although it was still lower than 2013 which was at 5.56 percent. In 2016 China rose slightly from 6.7 percent to 6.8 percent. Whereas the United States despite being a bit rowdy with its new leader, the economy strengthened from 1.7 percent to 1.9 percent and Singapore rose from 1.1 percent to 1.8 percent [1]

The Creative Industry Sector in 2016 grew by around 7 percent. Whereas in the period of 2014 - 2015, the added value of the creative industry sector was estimated to reach Rp. 111.1 trillion. The highest contributors to value added include the fashion, culinary and handicraft sub-sectors. The highest growth was achieved by the handicraft subsector with an export growth rate of 11.81 percent, followed by fashion with growth of 7.12 percent, advertising of 6.02 percent and architecture of 5.59 percent [2]. With these results, the central government and local government as well as the public must remain consistent in maintaining and carrying out development because of the severe global challenges.

Considering the many industry sectors that are relevant, in this study, researchers will limit the sectors of Design, Fashion, Publishing and Printing, especially in Jakarta and Bandung. Based on the background of the problem, it turns out that the creative industry as part of the creative economy has not become a serious concern from the local government, various problems that can be identified by researchers include; government equipment, especially in areas that are not ready to anticipate the development of creative industries, human resources are still very limited, infra-structure is minimal and also capital limitations of creative industry players, of the many problems that can be identified by researchers, the problems raised in this study are will be limited to how the actual mapping of creative industries in Jakarta and Bandung, and how far the students' understanding as a source of the development of educated human resources towards the creative industry. In the context of the problem, the researcher focused on mapping the creative industry, especially in the fields / subsectors of design, fashion, publishing and printing in Jakarta and Bandung. In general, the problems in this study can be identified as problems related to the understanding of students 
and the government, especially local governments, the development of creative industries in Bandung and Jakarta.

In this paper the focus of the problem is on how far the level of understanding of students in the creative industry and how creative industry to operation run their businesses. More specifically, there are two focus issues in this study, namely: (1) Mapping creative industries in the fields of Design, Fashion, cracking and publishing. In Jakarta and Bandung; and (2) To get an overview of students' understanding of the creative industry.

To give more direction to this research, the focus of the problem is described in the form of the following research questions: how do you map the creative industries in Jakarta and Bandung and how is the general understanding of students (students and students) about the creative industry.

\section{RESEARCH METHODS}

This research method uses quantitative methods supported by qualitative data, but researchers also refer to the testing of paradigmatic logical inference (Quantitative Logic Inference). While the data is analyzed by regression techniques. The subjects of this study were students from 7 public and private High Schools (SMA) in Bandung and Jakarta, as well as students from three public and private universities in Bandung and Jakarta. While from the business world as many as 15 research subjects consisting of companies operating in the creative industry sector consisting of 5 Graphic Design and Printing sub-sectors, only 3 printing companies, and 7 fashion companies (fashion development, convection and trading services). In addition, researchers also used secondary data obtained from the Office of Cooperatives, Small and Medium Enterprises (SMEs), and Trade Industry, City of Bandung and the Office of Cooperatives, Small and Medium Enterprises and Trade, Special Capital Region of Jakarta (DKI) Jakarta.

\section{A. Maintaining the Integrity of the Specifications}

The template is used to format your paper and style the text. All margins, column widths, line spaces, and text fonts are prescribed; please do not alter them. You may note peculiarities. For example, the head margin in this template measures proportionately more than is customary. This measurement and others are deliberate, using specifications that anticipate your paper as one part of the entire proceedings, and not as an independent document. Please do not revise any of the current designations.

\section{RESULTS AND DISCUSSION}

Creative industry is its own industry with an appearance on the excellence of creativity in producing creative designs that are attached to the goods / services produced. Creative industry is a collection of industrial sectors that prioritize creativity as the main capital in producing goods and services. The design industry in this case can be seen as a core component of a creative industry, where implementation can occur in various sectors. Industry was developed to support product value added in developing existing industrial clusters. Creative industry is an industry that can be used as a mainstay industry. According to Febrian [3], the characteristics of the creative industry can be expressed as follows:
- Industries whose main elements are creativity, expertise and talents that have the potential to improve welfare through the offering of intellectual creations.

- The creative industry consists of providing creative products directly to customers and supporting creative value creation in other sectors that indirectly relate to customers.

- $\quad$ Products from the creative industry have characteristics of short life cycles, high margins, high diversity, high competition, and easy replication.

In the creative industry component, the main capital of the creative industry is intellectual, and the creative industry contains elements of art, technology and business culture. For more details, here is Figure 1 regarding the components of the creative industry.

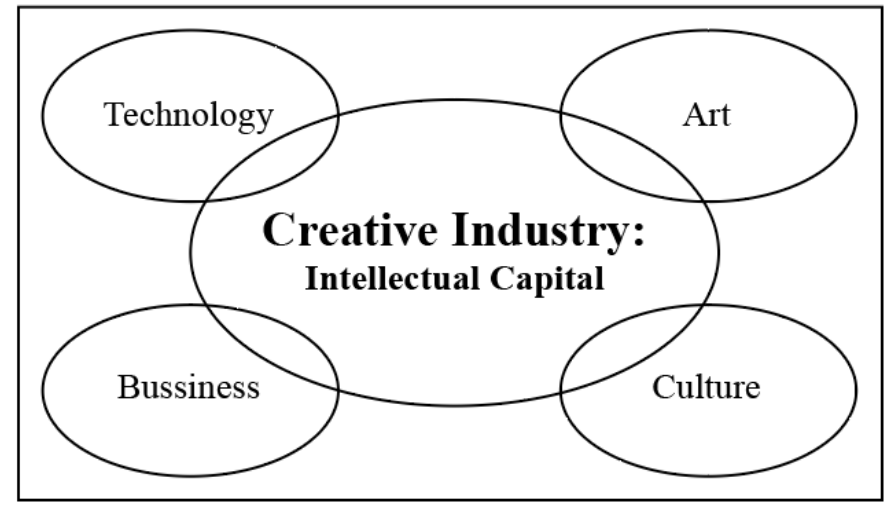

Fig 1. The components of the creative industry.

The description of the development of creative industries in Jakarta and Bandung is relatively the same, there are only a few sub-sectors of the creative industry that are special characteristics in each city, as in Bandung it is more prominent in fashion and textiles while in Jakarta it is more prominent in the field of software and animation development, as well as fashion.

The creative industry subsector of Graphic Design, Fashion, Publishing and Printing as a group of micro and small businesses both in Jakarta and Bandung in terms of turnover earned every month is relatively different, meaning that in terms of monthly sales turnover of between Rp. 10 million to Rp. IDR 60 million with a permanent workforce of between 2 and 6 people. As for the creative industry sub-sector with a higher turnover, between Rp500 million and Rp950 million, all of them are engaged in fashion.

The fashion creative industry subsector is still the most sought-after business by creative industry players that has been running today as well as by students who are prospective creative industry players in the future. This is also supported by the data that the fashion-related sub-sector is far more than the other creative industry sub-sectors. The understanding of students in the field of creative industries still shows unsatisfactory results, because only $42 \%$ really understand what the creative industry is, the rest of the students understand the creative industry as a manufacturing industry and an industry that is only skill-based. 
The implementation of the Tri Dharma Perguruan Tinggi is implementing Education, Research and Community Service, lecturers and students, has produced a lot of research, not to mention other research institutions both government and community / private. But the extent to which the results of this research can be adopted by the user market is still a big question mark for all of us. Apart from this there still seems to be innovation that can be expected from scholars or academics to be able to do much in taking a strategic role, so as to improve the welfare of the nation's dignity. One of the real forms of this innovation is the creativity of Indonesian human resources to process the resources they possess and the natural resources of Indonesia at this time continuously and responsibly, among others in the form of Creative Industries.

The development opportunities of the Creative Industry in Indonesia which adopted the Triple Helix pattern (Academics / Scholars, Business / Industry and Government) synergized together to advance creativity. Creative industries are defined as industries that focus on the creation and exploitation of intellectual property works. There are 16 Creative Industries sub-sectors, namely: performing arts, fine arts, television and radio, game applications, architecture, interior design, visual communication design, advertising, music, publishing, photography, product design, fashion, animation and video films, craft and culinary. This creative industry comes from ideas, art and technology that are managed to create prosperity. the excess of the creative industry is not too related to the world crisis. Because the creative industry uses raw materials that are widely available, then with creative human creation and design can produce attractive products, this does not seem to be too affected by the global crisis.

The challenges of the creative industry today are, among others, relatively new and not significant in driving the wheels of development, creative industry activities are still fragmented and there is no complete value chain study starting from the activities of creation, production and distribution, then the development of human resources in universities high also not much empower the creative industry.

The concept and direction of fostering the creative industry in Indonesia does not yet have an understanding or a single model of coaching specifically. coaching the creative industry can be understood very differently according to the perspective of people as well as the institutional, political and sociocultural context. In this case Ramli [4] stated as follows:

- The fashion creative industry subsector is still the most sought-after business by creative industry players. This data is also supported by the fact that the number of fashion-related sub-sectors is far more than the other creative industry sub-sectors; and (3) The understanding of students in the field of creative industries still shows unsatisfactory results, because only $42 \%$ really understand what the creative industry is.

- The creative industry sub-sector of Graphic Design, Fashion, Publishing and Printing as a group of micro and small businesses both in Jakarta and Bandung, in terms of turnover obtained every month is relatively different, meaning that in terms of monthly sales turnover of an average of between Rp10 million up to IDR 60 million with a permanent workforce of between 2 and 6 people. As for the creative industry sub-sector with a higher turnover, between Rp500 million and Rp950 million, all of them are engaged in fashion.

- The fashion creative industry subsector is still the most sought-after business sector by creative industry players that are currently running as well as by students who are prospective creative industry players in the future. This is also supported by the data that the fashion-related sub-sector is far more than the other creative industry sub-sectors.

\section{CONCLUSION AND SUGGESTIONS}

\section{A. Conclusion}

The conclusions of this paper is that the development of creative industries in Jakarta and Bandung is relatively the same, there are only a few sub-sectors of the creative industry that are special characteristics in each city, such as in Bandung more prominent in fashion and textiles while in Jakarta it is more prominent in the field of software and animation development, as well as fashion, other than that other conclusions are:

"Understanding the development of the creative industry as a process of developing, building, self-supporting and strengthening the bargaining position of the lower layers of society against the pressure forces in all fields and sectors of life. There is also another side that emphasizes that creative industry coaching is the process of facilitating youth as part of the community together on a common interest or affairs that collectively can identify targets, gather resources, mobilize an action campaign and therefore help reconstitute strength in the community".

The development of creative industries among youth is a process to create independent human resources. The ability of a country to compete in industry depends on the level of creativity. In the era of creative industry if a nation wants to advance, it must complete its technological capabilities (hitech) in order to be able to achieve high concept and high touch levels. High concept is the ability to create artistic and emotional beauty, recognize patterns and opportunities to create beautiful narratives that produce findings that others have not realized / found. High touch is the ability to empathize, understand the essence of human interaction, and find meaning [5].

\section{B. Suggestions}

- The government and the education sector must further socialize a more structured and massive creative industry especially the creative industry sub-sector outside fashion so that the creative industry can develop well.

- The Bandung City Government and DKI Jakarta Province must improve the infrastructure that can support the development of the creative industry, while also facilitating the credit process for business capital 
for actors and potential creative industry players who are increasingly interested in the year.

- The world of education, especially higher education and secondary education (vocational) must begin to pay attention to the creative industry sub-sector by starting to organize an appropriate curriculum and formed a kind of "idea center" in every educational institution so that the development of the creative industry is getting better and supported with human resources which is in accordance with the needs of the creative industries in their respective regions. To get a more comprehensive picture of the results of this study, further research is needed with broader variables and research objectives.

\section{REFERENCES}

[1] F. Ariyanti. BPS: Ekonomi RI Tumbuh 5,02 Persen di 2016. 2017. [Online]

Available

at: https://www.liputan6.com/bisnis/read/2847881/bps-ekonomi-ri-tumbuh502-persen-di-2016.

[2] Unknown. http://www.kemenperin.go.id / article / 12797 / Minister of Industry: -Industry-Creative-Grow-7-Per-Year.

[3] R.W. Febrian. Development of Creative Industries Cross Culture on SMEs Among Indonesian and Malaysian Youth. Literature and Social Sciences, Sociology of Anthropology, Universiti Malaya Kuala Lumpur. 2011.

[4] R. Ramli. Renewal and Empowerment. Problems, Criticism, and Ideas for a Future Indonesia. Jakarta: UI Press. 2009.

[5] D.H. Phink. A Whole New Mind, Riverhead Books, New York. 2005. 